УДК 37(091) (438) : 37(477)

DOI: https://doi.org/10.35619/iiu.v0i9.128

Баліка Людмила

кандидат педагогічних наук, доцент, доцент кафедри теорії і методики виховання

Рівненського державного гуманітарного університету,

м. Рівне, Україна

ORCID: 0000-0003-0042-7744

e-mail: liudmyla.balika@rshu.edu.ua

\title{
ТВОРЧЕ ВИКОРИСТАННЯ ІДЕЙ ДИТИНОЦЕНТРИЗМУ ЯНУША КОРЧАКА В СУЧАСНІЙ СИСТЕМІ ОСВІТИ УКРАЇНИ
}

\begin{abstract}
Анотація. У статті акцентовано увагу, що серед базових цінностей розвитку освітньої сфери стрижневим вектором $\epsilon$ цінності дитиноцентрованої освіти. Зазначено, що в концепції «Нова українська школа» передбачено новий зміст освіти, заснований на формуванні компетентностей, необхідних для успішної самореалізації дитячої особистості в суспільстві, педагогіку, що грунтується на партнерстві між учнем, учителем і батьками, орієнтації на потреби учня в освітньому процесі, дитиноцентризмі - ключовими компонентами, 3 яких складається формула нової школи. 3'ясовано, що дитиноцентризм постає провідним принципом освітньо-виховної діяльності на загальнодержавному рівні.

Зазначено, що серед розмаїття сучасних педагогічних теорій не втрачають актуальності та значимості прогресивні ідеї польського педагога-гуманіста Януша Корчака. Схарактеризовано творче використання ідей дитиноцентризму Я. Корчака у Володарській загальноосвітній санаторній школі-інтернаті I-III ступенів, Київській гімназії східних мов № 1, дитячому будинку «Перлинка» (м. Одеса), гімназії-інтернату № 13 (м. Київ). Зосереджено увагу, що педагогічні колективи цих закладів освіти творчо використовують ідеї польського педагога стосовно соціально-педагогічного знання та технологій роботи 3 дітьми-сиротами і дітьми, що потрапили у складні життєві обставини; вони прагнуть зберегти основні елементи системи, розробленої Я. Корчаком, і наповнити іï новим змістом.
\end{abstract}

Ключові слова: дитиноцентризм, Януш Корчак, творче використання, система освіти.

Постановка проблеми. Позитивні зміни, яких очікує суспільство, передбачають окреслення базових цінностей розвитку освітньої сфери, серед яких стрижневим вектором $є$ цінності дитиноцентрованої освіти. Це, як зазначає В. Кремень, передбачає, окрім гуманізації відносин і середовища, якнайповніше i точніше врахування природних основ дитячого розвитку індивідуальних, фізичних, психічних, пізнавальних особливостей i можливостей дітей, соціальних умов їх життя (2016, с. 56).

Концептуальні засади реформування середньої освіти, що визначені в Концепції «Нова українська школа», передбачають новий зміст освіти, заснований на формуванні компетентностей, необхідних для успішної самореалізації дитячої особистості в суспільстві, педагогіку, що грунтується на партнерстві між учнем, учителем і батьками, орієнтації на потреби учня в освітньому процесі, дитиноцентризмі, що $\epsilon$ ключовими компонентами, 3 яких складається формула нової школи. Документом визначено, що нова українська 
школа буде працювати на засадах особистісно орієнтованої моделі освіти, у межах якої вона повинна максимально враховувати здібності, потреби та інтереси кожної дитини, на практиці реалізуючи принцип дитиноцентризму (2017).

Отже, дитиноцентризм постає провідним принципом освітньо-виховної діяльності на загальнодержавному рівні, тому розкриття змісту цього поняття, його вивчення як педагогічної проблеми становить один із пріоритетних напрямів розвитку сучасної педагогічної науки.

Аналіз останніх досліджень 3 проблеми. Переорієнтація на людиноорієнтований підхід та гуманізацію в освіті отримала своє обгрунтування в працях П. Скляр та Т. Уманської (2007); сучасні наукові засади дитиноцентрованої педагогіки досліджується в наукових студіях С. Білецької (2008), О. Квас (2011), Л. Ярославцевої (2013) та ін. Окремі аспекти проблеми виховання в сучасних умовах висвітлюють В. Кемінь, О. Невмержицька (2014).

В Україні різні аспекти спадщини Я. Корчака вивчають М. Головко (2012), А. Діденко (2012), Т. Кущ (2011), В. Тихолоз (2013) та ін.

Мета статті. Здійснити аналіз впровадження ідей дитиноцентризму Я. Корчака в сучасному освітньому просторі.

Виклад основного матеріалу дослідження. Розмаїття сучасних педагогічних теорій не позбавляе актуальності та значимості прогресивних у свій час ідей педагогів минулого, які сьогодні розкриваються по-новому і тим самим вносять важливі корективи в сучасну педагогічну науку. 3-поміж них чільне місце посідає постать видатного польського педагога-гуманіста Януша Корчака.

У процесі здійснення нами аналізу педагогічної спадщини польського педагога-реформатора XX ст. Януша Корчака було з'ясовано, що провідними елементами в його літературно-педагогічній творчості та професійній діяльності $€$ : положення: любов до дитини, визнання рівноцінності (рівноправності) у взаємодії дитини та дорослого, повага до дитини та ії прав, опора на позитивне в особистості дитини і дитячому колективі; принципи: індивідуального підходу до дитини, партнерства між дитиною та дорослим, діалогізму, самовиховання, самоуправління, зв'язку виховання 3 життям (трудова діяльність (трудова компетентність)); цінності: здоров'я дитини, почуття безпеки, авторитет дитини в світі дорослих, моральність як дієвий, впливовий чинник формування підростаючої особистості, творчість дитини та розвиток задатків до творчості як психологічний механізм зменшення негативних явищ і загрозливих умов середовища в процесі соціалізації й адаптації.

Сукупність цих елементів визначаємо як основні положення дитиноцентризму, який $є$ стрижневим у педагогічних поглядах видатного польського педагога і складає сутність його педагогічної практики.

Педагоги комунального закладу «Володарська загальноосвітня санаторна школа-інтернат I-III ступенів» Київської області активно впроваджують творчу спадщину Януша Корчака у свою діяльність.

«Реформувати світ - означає реформувати виховання», - вважав Я. Корчак. Педагог вимагав від дорослих: поваги до неосвіченості дитини; поваги до її невдачі і сліз; поваги до власності дитини та їі бюджету; поваги до таємниць дітей; поваги до поточного моменту; поваги до життя свідомого і відповідального (Некраш, 2017, с. 212). 
T. Некраш зазначає, що життєзнавство - це нова філософія освіти, спрямована на виховання конкурентоспроможної, компетентної, соціально мобільної особистості, яка вміє приймати рішення і нести за них відповідальність (2017, с. 211).

Володарська загальноосвітня санаторна школа-інтернат I-III ступенів - це школа Життєзнавства, в якій дитина набуває життєвої компетентності, вчиться мистецтву жити. Тут дитина осмислює своє власне життя, визначає свої життєві орієнтири, навчається самостійно розв'язувати свої проблеми й ухвалювати виважені рішення, вчаться нести відповідальність за власне життя i вчинки.

Особливостями змісту інноваційної діяльності школи життєзнавства є: педагогічне проектування, відкритий виховний простір, модернізація класноурочної системи навчання, впровадження допрофільної підготовки вихованців, залучення учнів до проектної діяльності й соціальної практики, забезпечення соціального, психологічного та медичного супроводу освітнього процесу.

Кожне навчальне заняття - це крок у розвитку інтелекту учня, цеглина в підмурівок чарівного будинку на ім'я досвід і знання, без яких неможлива діяльна особистість.

Для досягнення цієї мети педагоги запроваджують у свою роботу авторські життєтворчі програми, виховні проекти, основними завданнями яких $\epsilon$ розвиток життєвих компетенцій учнів.

Педагоги комунального закладу «Володарська загальноосвітня санаторна школа-інтернат I-III ступенів» активно впроваджують гуманістичні ідеї педагогіки Януша Корчака у свою діяльність. Зокрема, беруть активну участь у Міжнародних конференціях, присвячених педагогічним ідеям Я. Корчака; в закладі проводять круглі столи, семінари «Як любити дітей», організовують міні-виставки, присвячені життю та діяльності педагога.

У колективі систематично проводять педагогічні ради на тему «Уроки Януша Корчака для комунального закладу «Володарська загальноосвітня санаторна школа-інтернат I-III ступенів», де педагоги ознайомлюються із напрямами реалізації ідей та принципів виховної системи Януша Корчака: уроки «Як любити дитину», «правила життя» й організація життя вихованців школи-інтернату, а також право дитини на повагу. Творчі групи виробили свої поради та правила життя для учнів санаторної школи-інтернату (Некраш, 2017, c. 215).

У Київській гімназії східних мов № 1 впроваджено суспільствознавчий курс «Людина і світ», завдання якого співзвучні із завданнями, які вирішував польський педагог Я. Корчак. В гімназії розроблено інтеграцію педагогічних умов Я. Корчака до змісту вивчення окремих тем, питань (Савченко, 2017).

Приміром, під час розгляду вступу до змісту навчального матеріалу 3 питання «Індивідуальність як феномен людини. Особа. Особистість» включено приклади ідей Я. Корчака про педагогіку як науку не про дітей, а про людей; про доброзичливе ставлення до людей як шлях до миру між народами; про дитину як людину.

Вивчаючи теми «Соціалізація особистості», під час розгляду понять «соціалізація», «сім'я» наводяться ідеї Я. Корчака про створення оптимальних умов для всебічного розвитку дитини як особистості, про повагу до дитини нарівні $з$ іншими періодами життя; про формування моральної культури та 
фізичного здоров'я; про співпрацю вихователів і вихованців на засадах взаєморозуміння, співчуття.

Під час вивчення теми «Стереотипи та упередження» (питання «Поняття дискримінації. Ксенофобії. Расизм. Упередження. Толерантність») учні на основі випереджальних завдань представляють міні-твори про долю єврейських дітей-сиріт в окупованій німецькими нацистами Варшаві в роки Другої світової війни, які стали жертвами Голокосту, загинувши разом із директором Варшавського Будинку сиріт Янушем Корчаком у таборі смерті в Треблінці. Учні роблять відповідні висновки у контексті питань, що розглядаються.

Вивчення теми «Права, свободи та відповідальність» збагачується доповненнями про права дитини ідеями Я. Корчака, який розробив перелік прав дитини, що їх обов'язково мають дотримуватися дорослі - батьки, вчителі і вихователі: право дитини на навчання, школу і книжки; право дитини на співпрацю з дорослими, а також на самобутність; право дитини на повагу, на особисту таємницю; право на діалог з дорослими, на висловлювання своїх думок, оцінок і позицій; право дитини на помилки і самостійне їх вирішення (Савченко, 2017, с. 263).

Гімназисти 11 класу, порівнюючи ці права з Конвенцією ООН про права дитини, пропонують свої доповнення до міжнародних стандартів прав дитини.

Розглядаючи тему «Демократія», учні використовують надбання досвіду Я. Корчака щодо організації учнівського самоврядування - моделі соціальних відносин у Варшавському Будинку сиріт, у «Нашому домі» - двох окремих «дитячих республіках».

У дитячому будинку «Перлинка» (м. Одеса) впроваджується програма трудового виховання, що спирається на ідеї Януша Корчака. Адже найважливіший механізм соціального досвіду дитини - це іiі трудове виховання. Мета освітньо-виховної та соціально-педагогічної діяльності дитячого будинку «Перлинка» - забезпечення самореалізації особистості вихованця, випускника закладу освіти. Самореалізація $\epsilon$ найкращою особистісною гарантією успішної життєдіяльності вихованця, яка може бути закладена у процесі виховання саме у дитячому будинку. Вона досягається шляхом розкриття, розвитку та реалізації духовного, творчого потенціалу вихованців, пошуку та віднайдення їхнього професійного покликання (Петрова, 2017).

Мета програми трудового виховання та ранньої профорієнтації вихованців дитячого будинку - сформувати стійкі орієнтації на трудовий спосіб життя, трудову культуру особистості, забезпечити практичну та морально-психологічну готовність до творчої праці, виховати моральне ставлення дітей до трудової діяльності, розвинути творчі здібності вихованців. Головна особливість трудового виховання дітей-сиріт і соціальних сиріт потреба у творчому характері праці, створенні умов для розкриття, розвитку й реалізації у процесі виховання задатків та здібностей дитини. Трудове виховання спрямовується на заохочення та реалізацію пізнавального інтересу, забезпечення конструктивного спілкування з однолітками та дорослими, у будь-якій роботі, яку виконують вихованці «Перлинки», беруть участь i дорослі: молодші допомагають, навчаються на прикладі педагогів i співробітників; старші стають повноправними партнерами дорослих або можуть виконати доручену їм роботу самостійно. Схожий підхід до організації 
дитячої праці був і в Я. Корчака: «перш ніж доручити дітям вимити або натерти підлогу, неодноразово зробити це самому і дивитися, як це роблять діти, і уважно вислухати, що вони скажуть. Можна ... власним приклад показати, що немає брудної роботи» (Корчак, 1979, с. 425-426).

В умовах дитячого будинку «Перлинка» вирішуються такі завдання трудового виховання: формування позитивного ставлення до праці як найвищої цінності в житті, високих соціальних мотивів трудової діяльності, потреби в творчій праці. Але найголовніші завдання - це підготовка до свідомого вибору професії, формування культури праці, працьовитості, почуття обов'язку і відповідальності, цілеспрямованості, вміння планувати свою діяльність, вміння співпрацювати в колективній трудовій діяльності.

Становлення та розвиток особистісних детермінант самореалізації охоплює всі сфери життєдіяльності вихованця: його духовне й трудове виховання; формування пізнавальних інтересів; спілкування, навчання (із застосуванням розвивальних, інтерактивних, ігрових методів, методу проектів), трудову діяльність у навчально-виробничих майстернях. Очікувані результати реалізації програми трудового виховання та ранньої профорієнтації: психологічна та практична готовність дітей до праці; виявлення інтересів та нахилів; формування позитивного ставлення до праці, культури праці; виявлення напряму трудового навчання; формування готовності до самореалізації у трудовій діяльності (Петрова, 2017, с. 302).

Змістовну основу трудового виховання в дитячому будинку складають такі види праці: навчальна праця (робота в теплиці, у столярній і швацькій майстернях); суспільно корисна праця (самообслуговування, побутова праця, догляд за рослинами); продуктивна праця (бригада з ремонту, робота у своїх теплицях та збирання врожаю, трудові загони, робота за наймом).

Принципи формування трудової свідомості i трудової активності: вихованець повинен усвідомлювати, що його праця має певну суспільну значущість, приносить користь людям, колективу, суспільству. Це може бути праця на користь дитячого будинку (робота на ділянці, оформлення дитячого будинку, ремонт навчальних посібників, благоустрій та озеленення подвір'я); результатом праці обов'язково повинен бути корисний продукт, що має певну суспільну цінність. Вихованець повинен ясно, зримо бачити реальні результати своєї праці; праця повинна бути колективною. Колективна праця дозволяє ставити і розв'язувати завдання, виконання яких не під силу окремо взятій людині, дає можливість дітям набути досвід трудової взаємодопомоги та солідарності; праця вихованця повинна бути ініціативною і творчою. Що більше інтелектуальних зусиль вимагає праця, то з більшою готовністю будуть займатися нею діти; необхідно вимагати від вихованців не просто виконання роботи, а ретельного, акуратного, сумлінного виконання, дбайливого ставлення до обладнання, матеріалів, знарядь праці (Петрова, 2017, с. 303).

Усі компоненти трудового виховання дітей здійснюються поетапно, 3 урахуванням віку, на основі принципів цілісності, безперервності. До 12 років трудове виховання реалізується переважно на базі дитячого будинку. Першим етапом стає розвиток навичок самообслуговування та оволодіння побутовими навичками. Надалі трудове виховання відбувається через роботу студії «Вмілі рученята» (гуртки: «Глиняне диво», «Дерев’яні візерунки», «Іграшка своїми руками», «Столярна майстерня», «Швацька майстерня», «Теплиця», «Кулінарна академія» «Фотомистецтво» та ін.). 
Багато батьків, учителів, педагогів вважають оплату дитячої праці «непедагогічною». Педагоги дитячого будинку «Перлинка» не погоджуються 3 цим твердженням. Вони розділяють думку Я. Корчака, який вважав: «Чому ми не повинні, і якомога раніше навчити дитину розуміти, що таке гроші і плата за працю, щоб дитина знала ціну незалежності, яку дає заробіток; щоб дитина знала погані і добрі сторони володіння власністю?» (Корчак, 1990, с. 227). Вихованці, що досягли 12 років, завдяки програмі «Соціальне партнерство» під час канікул працюють (в автомайстерні, на приватній фабриці з виготовлення меблів, у квітковому магазині, у кухні ресторану, у перукарні тощо). Таким чином, вони заробляють гроші, самостійно їх витрачають, що їм, як дітямсиротам, дає можливість вникнути в окремі нюанси економічних відносин. Хлопчики працюють у домашній столярній майстерні, допомагають у господарських справах у домі (ремонт меблів, виготовлення табуретів, полиць та ін.). У швацькій майстерні дівчатка, починаючи 3 п'ятого класу, можуть шити прості речі для себе (білизну, плаття, літні костюми). Діти мають можливість бачити результати своєї праці, порівнювати якість виконаної роботи з роботою інших вихованців, відчувати необхідність і значущість своєї праці для інших людей. У зв'язку з цим у дитячому будинку регулярно організовуються виставки дитячих робіт, із запрошенням гостей, які беруть участь у вихованні дітей. Безперечно, паралельно відстежується регулярний зріз інтересів дітей методами інтерв'ю і творів-роздумів. На початку 9 класу профорієнтаційна робота доповнюється психологічною діагностикою схильностей вихованця, що супроводжується індивідуальними бесідами. Це має допомогти вихованцю обрати після випуску те навчання, яке відповідатиме його інтересам та здібностям.

Педагогічний колектив дитячого будинку «Перлинка», значною мірою спираючись на методику виховання Я Корчака, розробив низку авторських педагогічних програм, пов'язаних 3 трудовим вихованням і профорієнтацією дітей-сиріт, і втілює їх у життя.

Своєю чергою, і в гімназії-інтернаті № 13 м. Київ втілюються провідні положення педагогічної системи Януша Корчака. Стратегічна мета закладу навчити дітей жити у світі, який постійно змінюється, спонукати їх самих виступати в ролі «носіїв змін». Пріоритет вільного розвитку дитини $є$ базовим принципом побудови освітньо-виховної системи закладу.

Педагогічний колектив ставить перед собою такі завдання: зрозуміти кожну особистість та виявити до неї повагу; розвинути здібності критичного мислення й незалежного висловлювання; розвивати спроможність приймати самостійні рішення; прищепити необхідні навички 3 базових предметів; розвинути емоційний інтелект дитини; надати необхідну індивідуальну педагогічну підтримку; розвинути самосвідомість кожного учня як самостійної самодостатньої особистості і як члена колективу (Дзюба, 2017).

Колектив гімназії-інтернату № 1 бере до уваги права дитини, потреби i сподівання дитини, водночас заохочує дітей до праці над собою за Я. Корчаком.

У виховному просторі гімназії-інтернату педагоги намагаємося зміцнювати дух толерантності і формувати відносини відкритості, уваги один до одного та солідарності. Вони переконані, що засоби комунікації здатні відігравати конструктивну роль у сприянні вільному та відкритому діалогу, поширенню цінностей толерантності та роз'ясненню небезпеки проявів 
байдужості до випадків інтолерантності, насамперед, у формі нетерпимості й насильства.

3 метою формування в учнів життєвих навичок соціальної компетентності - базису для адаптивної та позитивної поведінки, які дозволяють гімназистам адекватно сприймати і виконувати норми і правила, прийняті в суспільстві, ефективно вирішувати проблеми повсякденного життя, - проводять заняття з курсу «Культура життєвого самовизначення».

Культура життєвого самовизначення - це активне визначення людиною своєї позиції стосовно суспільної системи цінностей (моральних, соціальних, комунікативних, естетичних, професійних тощо), що дає їй змогу виявляти й утверджувати себе у різних життєвих ситуаціях.

На заняттях вихователі формують в учнів життєві навички соціальної компетентності - базис для адаптивної та позитивної поведінки, які дозволяють гімназистам адекватно сприймати і виконувати норми і правила, що утвердилися в суспільстві, розв'язувати проблеми повсякденного життя. У своїй роботі педагоги роблять акцент на формуванні таких життєвих навичок, як: комунікація (спілкування); прийняття рішень; критичне і творче мислення; управління емоціями, стресами та конфліктними ситуаціями; розпізнавання та формування цінностей (Дзюба, 2017, с. 334).

На виховних годинах, годинах спілкування «Культура життєвого самовизначення» гімназисти навчаються робити самоаналіз навчальної діяльності та самооцінку результатів особистого внеску у колективну справу. Без такого самоаналізу учні часто стають пасивними споглядачами справ колективу. Після заняття з теми «Велика радість - творити добро» гімназистки дійшли висновку: чим довше людина перебуває в середовищі добра, тим швидше правильні вчинки і поведінка стають внутрішніми переконаннями, нормою життя. Тому лідери учнівського самоврядування «Сдина родина» реалізували такий соціальний проект, як «Моральні чесноти як основа формування лідерства - служіння».

На морально-етичних заняттях 3 курсу «Культура життєвого самовизначення» діти створюють сюжетні малюнки, що передбачають логічно вибудовану канву діалогічної взаємодії педагога і дітей, спільних міркувань, пошуку відповіді або рішення, у процесі якого народжуються оціночні судження, що спонукають дітей до засвоєння морально-ціннісних орієнтирів.

У гімназії-інтернаті до освітньо-виховного процесу залучаються батьки. Організовуються для батьків вечори, зустрічі, свята, майстер-класи «Професійний вернісаж», «Таланти наших батьків», мета яких - мобілізувати творчий потенціал батьківської громади гімназії. Учнівські колективи гімназії також звітують перед батьками під час гімназійного фестивалю «Сходинки із класу в клас».

Аби пом'якшити проблему конфліктів між дітьми та батьками, гармонізувати взаємини у родині в гімназії проводяться волонтерські, благодійні акції, де батьки та діти є однодумцями, задіяні в єдиному процесі співпраці та співтворчості. Прикладом доброчинної діяльності учнівської молоді є такі акції та соціальні проекти: «Я дар від серця принесу», «Добро починається 3 тебе», «Діти Києва - діти Авдіївки».

Учнівське самоврядування $€$ активним учасником освітньо-виховного процесу у трикутнику співпраці Учні - Педагоги - Батьки. Я. Корчак у самоврядуванні вбачав шлях до створення сприятливих умов для розвитку $\mathrm{i}$ 
соціального становлення кожної дитини, законного забезпечення та захисту іiі прав. Завдання, які стоять перед учнівським колективом гімназії-інтернату, фокусуються навколо проблем життєвої компетентності кожного гімназиста, а це вимагає постійної роботи над собою, посилення відповідальності молодої людини за своє майбутнє.

Висновки і перспективи подальших розвідок. Аналіз досвіду творчого використання ідей Я. Корчака щодо дитиноцентризму у сучасній педагогічній практиці доводить, що більшість ідей Януша Корчака можуть бути успішно застосовані у практиці роботи сучасних закладів освіти. Педагогічні колективи, які впроваджують ідеї польського педагога, прагнуть зберегти основні елементи системи, розробленої Я. Корчаком, і наповнити іiі новим змістом, виходячи $з$ конкретних умов роботи свого закладу, рівня розвитку дітей, матеріальної бази, власних можливостей тощо.

\section{СПИСОК ВИКОРИСТАНИХ ДЖЕРЕЛ:}

Національна академія педагогічних наук України, (2016). Національна доповідь про стан і перспективи розвитку освіти в Україні. Київ : Педагогічна думка. 448 с.

Бабік, Н. (2017). Нова українська школа: порадник для вчителя. Київ: ТОВ «Видавничий дім «Плеяди». 206 с.

Скляр, П. та Уманська, Т. (2007). «Гуманізація» та «гуманітаризація»: поняття, співвідношення та шляхи впровадження в освіту. Вісник Національного технічного університету Украӥни «Київський політехнічний інститут». Філософія. Психологія. Педагогіка, [online] № 1. Режим доступу: http://www.nbuv.gov.ua/portal/soc_gum/VKPI_fpp/2007-1/index.html [Дата звернення 6 березня 2019]

Білецька, С. (2008). Дитиночентрована педагогіка. Теорія $і$ практика західних країн. Харків : Факт. 260 с.

Квас, О. (2011). Дитиночентризм через призму сучасних гуманітарних досліджень. Шлях освіти, № 3. С. 14-18.

Ярославцева, Л. (2013). Ідеї дитиноцентризму в теорії і практиці вітчизняної педагогіки на рубежі XIX-XX ст. Педагогічні науки : Вісник ЛНУ імені Тараса Шевченка. № 13, ч. 1. с. 289-296.

Кемінь, В. Невмержицька, О. та Чех, А. (2014). Порівняльна педагогіка : навч.-метод. посіб. Дрогобич : Видав. відділ ДДПУ імені Івана Франка. 320 с.

Головко, М. (2012). Проблема педагогічного супроводу дитинства в педагогіці Я. Корчака. Історико-педагогічний альманах Збірник наукових праиь Уманського державного педагогічного університету ім. Павла Тичини. Вип. № 1. c. 41-44.

Діденко, А. (2013). Місце дитячого самоврядування у виховній системі Януша Корчака. Педагогічний дискурс. Вип. 15. с. 199-202.

Кущ, Т. (2011). Соціальна адаптація дітей раннього віку : педагогічні погляди Януша Корчака. Актуальні проблеми сочіологї̈, психологї̈, педагогіки. № 13. с. 213 217.

Тихолоз, В. (2013). Історія сочіальної педагогіки: навч.-метод. посіб. для студентів спеціальності «Сочіальна педагогіка». Черкаси: Вид. від. ЧНУ ім. Богдана Хмельницького. 272 с.

Некраш, Т. та Глобець, О. (2017). Життєві смисли змісту освіти в сучасній школі. Філософія дитинства Януша Корчака. Фундаментальні потреби дитини в сучасному суспільстві: матеріали Міжнародної науково-практичної конференції з 
педагогіки та дитячої психологї̈, 7-8 квітня 2017p. Київ.: ДУХ І ЛІТЕРА. с. 211215.

Савченко, М. (2017). Актуалізація педагогічних ідей Януша Корчака в навчальному курсі «людина і світ» у гімназії. Філософія дитинства Януша Корчака. Фундаментальні потреби дитини в сучасному суспільстві: матеріали Міжнародної науково-практичної конферениї з педагогіки та дитячої психології, 7-8 квітня 2017p. Київ.: ДУХ І ЛІТЕРА. с. 259-266.

Петрова, С. (2017). Роль трудового виховання та ранньої професійної орієнтації в становленні особистості дитини-сироти. Філософія дитинства Януша Корчака. Фундаментальні потреби дитини в сучасному суспільстві: матеріали Міжнародної науково-практичної конферениї з педагогіки та дитячої психології, 7-8 квітня 2017p. Київ.: ДУХ І ЛІТЕРА. с.299-305.

Корчак, Я. (1979). Педагогическая публицистика. Избранные педагогические произведения. Москва: Педагогика. с. 405-450.

Корчак, Я. (1990). Как любить ребенка: Книга о воспитании. Москва: Политиздат, 493 с.

Дзюба, В. (2017). Розвиток життєвої компетентності особистості в умовах гуманістичного виховання простору. Філософія дитинства Януша Корчака. Фундаментальні потреби дитини в сучасному суспільстві: матеріали Міжнародної науково-практичної конферениї з педагогіки та дитячої психології, 7-8 квітня 2017p. Київ.: ДУХ І ЛІТЕРА. с.330-337.

\section{REFERENCES:}

Natsionalna akademiia pedahohichnykh nauk Ukrainy, (2016). Natsionalna dopovid pro stan $i$ perspektyvy rozvytku osvity v Ukraini [National Report on the State and Prospects of Education in Ukraine] . Kyiv : Pedahohichna dumka. 448 s. [in Ukrainian]

Babik, N. (2017). Nova ukrainska shkola: poradnyk dlia vchytelia [New Ukrainian School: Teacher's Guide]. Kyiv: TOV "Vydavnychyi dim "Pleiady". 206 s. [in Ukrainian]

Skliar,P. ta Umanska,T. (2007). "Humanizatsiia" ta "humanitaryzatsiia": poniattia, spivvidnoshennia ta shliakhy vprovadzhennia v osvitu. ["Humanization" and "Hhumanization": Concept, Relations and Ways of Implementation in Education]. $V$ Visnyk Natsionalnoho tekhnichnoho universytetu Ukrainy "Kyivskyi politekhnichnyi instytut". Filosofiia. Psykholohiia. Pedahohika, [online] No 1. Rezhym dostupu: http://www.nbuv.gov.ua/portal/soc_gum/VKPI_fpp/2007-1/index.html [Data zvernennia 6 bereznia 2019] [in Ukrainian]

Biletska,S. (2008). Dytynotsentrovana pedahohika. Teoriia i praktyka zakhidnykh krain [Child-centered Pedagogy. The Theory and Practice of Western Countries]. Kharkiv : Fakt. 260 s. [in Ukrainian]

Kvas,O. (2011). Dytynotsentryzm cherez pryzmu suchasnykh humanitarnykh doslidzhen. [Child-centeredness Through the Prism of Modern Humanities Research]. Shliakh osvity, No 3. S. 14-18. [in Ukrainian]

Yaroslavtseva,L. (2013). Idei dytynotsentryzmu v teorii i praktytsi vitchyznianoi pedahohiky na rubezhi XIX-XX st. [The Ideas of Child-centrism in the Theory and Practice of National Pedagogy at the end of the $19^{\text {th }}$ at the beginning of the $20^{\text {th }}$ Century]. Pedahohichni nauky : Visnyk LNU imeni Tarasa Shevchenka. No 13, ch. 1. S. 289-296. [in Ukrainian]

Kemin,V. Nevmerzhytska, O. ta Chekh, A. (2014). Porivnialna pedahohika : navch.-metod. posib. [Comparative Pedagogy: teaching method. manual]. Drohobych : Vydav. viddil DDPU imeni Ivana Franka. 320 s. [in Ukrainian]

Holovko,M. (2012). Problema pedahohichnoho suprovodu dytynstva v pedahohitsi Ya. Korchaka [The Problem of Pedagogical Support of Childhood in the Pedagogy Y. 
Korchak]. Istoryko-pedahohichnyi almanakh Zbirnyk naukovykh prats Umanskoho derzhavnoho pedahohichnoho universytetu im. Pavla Tychyny. Vyp. No 1. SS. 41-44 [in Ukrainian]

Didenko, A. (2013). Mistse dytiachoho samovriaduvannia u vykhovnii systemi Yanusha Korchaka [The Place of Children's Self-government in the Educational System of Yanush Korczak]. Pedahohichnyi dyskurs. Vyp. 15. S. 199-202 [in Ukrainian]

Kushch,T. (2011). Sotsialna adaptatsiia ditei rannoho viku : pedahohichni pohliady Yanusha Korchaka [Social Adaptation of Children of Early Age: Yanush Korczak's Pedagogical Views]. Aktualni problemy sotsiolohii, psykholohii, pedahohiky. No 13. S. 213-217 [in Ukrainian]

Tykholoz,V. (2013). Istoriia sotsialnoi pedahohiky: navch.-metod. posib. dlia studentiv spetsialnosti "Sotsialna pedahohika" [History of Social Pedagogy: teaching method. manual for students of the specialty "Social pedagogy"]. Cherkasy: Vyd. vid. ChNU im. Bohdana Khmelnytskoho. 272 s. [in Ukrainian]

Nekrash, T. ta Hlobets, O. (2017). Zhyttievi smysly zmistu osvity v suchasnii shkoli [The Vital Meanings of the Content of Education in Modern School]. V Filosofiia dytynstva Yanusha Korchaka. Fundamentalni potreby dytyny v suchasnomu suspilstvi: materialy Mizhnarodnoi naukovo-praktychnoi konferentsii $z$ pedahohiky ta dytiachoi psykholohii, 7-8 kvitnia 2017 r. Kyiv.: DUKh I LITERA. S. 211-215. [in Ukrainian]

Savchenko,M. (2017). Aktualizatsiia pedahohichnykh idei Yanusha Korchaka v navchalnomu kursi "liudyna i svit" u himnazii [Actualization of Yanush Korchak's Pedagogical Ideas in the Educational Course "Man and the World" at the Gymnasium]. $V$ Filosofiia dytynstva Yanusha Korchaka. Fundamentalni potreby dytyny v suchasnomu suspilstvi: materialy Mizhnarodnoi naukovo-praktychnoi konferentsii $z$ pedahohiky ta dytiachoi psykholohii, 7-8 kvitnia 2017 r. Kyiv.: DUKh I LITERA. S.259-266 [in Ukrainian]

Petrova,S. (2017). Rol trudovoho vykhovannia ta rannoi profesiinoi oriientatsii $v$ stanovlenni osobystosti dytyny-syroty [The Role of Labor and Early Professional Orientation in the Formation of Individual of an Orphan]. V Filosofiia dytynstva Yanusha Korchaka. Fundamentalni potreby dytyny $v$ suchasnomu suspilstvi: materialy Mizhnarodnoi naukovo-praktychnoi konferentsii z pedahohiky ta dytiachoi psykholohii, 78 kvitnia 2017 r. Kyiv.: DUKh I LITERA. S.299-305 [in Ukrainian]

Korchak,Ya. (1979). Pedagogicheskaya publitsistika [Pedagogical Publicism]. Izbrannyye pedagogicheskiye proizvedeniya. Moskva: Pedagogika. S. 405-450 [in Russian]

Korchak,Ya. (1990). Kak lyubit rebenka: Kniga o vospitanii [How to Love a Child: a Book about Upbringing]. Moskva: Politizdat. 493 s. [in Russian]

Dziuba,V. (2017). Rozvytok zhyttievoi kompetentnosti osobystosti v umovakh humanistychnoho vykhovannia prostoru [Development of Person's Vital Competence in Conditions of Humanistic Education of Space]. Filosofiia dytynstva Yanusha Korchaka. Fundamentalni potreby dytyny $\mathrm{v}$ suchasnomu suspilstvi: materialy Mizhnarodnoi naukovo-praktychnoi konferentsii z pedahohiky ta dytiachoi psykholohii, 7-8 kvitnia 2017 r. Kyiv.: DUKh I LITERA. S.330-337 [in Ukrainian]

\section{CREATIVE USE OF YANUSH KORCHAK'S IDEAS OF CHILD- CENTRISM IN THE MODERN SYSTEM OF EDUCATION OF UKRAINE}

Luidmyla Balika

Candidate of Pedagogical Sciences, Associate Professor, Associate Professor at the Department of Theory and Methodology of Education, Rivne State University of the Humanities, Rivne, Ukraine 
ORCID: 0000-0003-0042-7744

e-mail: luidmyla.balika@rshu.edu.ua

\begin{abstract}
The article deals with the problem of the basic values of the development of the educational sphere, the pivotal vector of which is the values of child-centered education. It is noted that the concept "New Ukrainian School" provides new content of education, which is based on the formation of the competencies which are necessary for the successful self-realization of the child's personality in the society, on a new content of pedagogy, based on a partnership between a student, a teacher and parents, on the orientation to the needs of the student in the educational process, child-centrism. These components are the key components of the new school formula. It is cleared that childcentrism is the leading principle of educational activity at the national level.

It is indicated that among the variety of modern pedagogical theories, the ideas of the Polish pedagogue-humanist, Yanush Korchak remain to be actual in their significance. It is revealed that the leading elements in his literary and pedagogical work and professional activity are the following ones: position, principles, values. The totality of these elements is defined as the key points of the child-centrism, which are pivotal in the pedagogical views of an outstanding Polish teacher and which form the essence of his pedagogical practice.

The creative use of the Y. Korchak's ideas of child-centrism in Volodarska I-III grades comprehensive sanatorium boarding school, Kyiv gymnasium of the eastern languages No 1, orphanage "Perlynka" (Odessa), gymnasium-boarding school No 13 (Kyiv) is analyzed. The attention is focused on the fact that the pedagogical collectives of these educational institutions creatively use the ideas of the Polish teacher regarding social and pedagogical knowledge and technologies of working with orphans and children who have been subjected to difficult living conditions; they adhere to the basic elements of the system developed by Y. Korczak, filling it with a new content.
\end{abstract}

Key words: child-centrism, Yanush Korczak, creative use, education system. Стаття надійшла до редакиії 10.04. 2019 р. 